\title{
Influence of Project Planning Processes on Construction Project Success in Nigeria
}

\author{
Khadija Kubra Ibrahim Dr. Cross Ogohi Daniel \\ Department of Business Administration, Nile University of Nigeria, Abuja FCT
}

\begin{abstract}
The success or failure of any construction project begins from the planning stage. Thus, the aim of this study investigates the influence of 19 project planning processes on construction project success measured by project efficiency and project effectiveness and also identify the most critical planning processes which have the highest influence on construction project success in Nigeria. In this study, a structured questionnaire was developed by using Likert scale and applied on 60 respondents. A total of three organizations in the Federal Capital Territory were surveyed. Construction project success acts as independent variable while project planning processes as dependent one. The method used for the research is quantitative and applied survey instrument for data collection. For data analysis purpose, SPSS is used for descriptive statistics. The results have shown that Creation of Work Breakdown Structure (WBS), Program Evaluation Review Technique (PERT) or Gantt Chart, Project Schedule Network, Determine Budget and Quality Management Plan have the highest awareness and usage by the selected firms and WBS has been found to be the most significant planning process. Additionally, the correlation between total level of planning and project success rho $(60)=-.493$ with $p=.032$, and between total level of planning and the efficiency component of project success $\operatorname{rho}(60)=-.618$ with $p=.005$, were statistically significant , given a $=.05$ (two tailed) while the correlation between total level of planning and the effectiveness component of project success was not statistically significant. Overall, an increasing awareness of project planning processes was observed and that has also led to the success of construction projects. The findings of this research therefore signify the necessity of frequent use of some other project planning processes like risk management plan, activity resource requirements in other to see better performance of construction projects. Continuous development seminars and trainings in project management should also be organized for all professionals in the sector both in private and government organizations.
\end{abstract}

Keywords: project planning processes, project success, construction projects.

DOI: $10.7176 / \mathrm{EJBM} / 12-9-05$

Publication date:March $31^{\text {st }} 2020$

\section{Introduction}

Construction Projects have a major role in the economy of many countries and especially in developing countries. According to Olawale \& Sun (2010), the construction industry contributes to the GDP and employment rate of many nations and for this reason, it is considered vital for the economic development of any nation. According to the Nigerian National Bureau of Statistics (NBS), economic growth in 2018 was driven by the non-oil sector, principally the construction and real estate sectors, which include cement and wood manufacturing. In this regard, the Nigerian federal government has earmarked about $30 \%$ of its 2018 budget on infrastructure projects. The capital expenditure has provided a stimulus for the construction industry and gear toward housing development (Nigeria Construction Equipment, 2018).

Ameh and Odusami (2010) stated that construction industry in Nigeria comprises a group of heterogeneous and fragmented firms and, within firms, there is often a great diversity of activities. In addition, they added that a large construction company may be engaged in activities ranging from general building and civil engineering to material manufacturing, property development, and trade specialization. According to Menches, Hanna, Nordheim \& Russel (2008), performance of any construction project involves numerous processes, with various permutations of stakeholders, typically including procurement, design, planning, execution and management of diverse tasks, control, site management and project closeout. Thus, the success of any project is measured by its end time, within the budget cost and meets the planned performance based on the initial plan. Hence, planning has an important role on the project success.

\subsection{Statement of the Research Problem}

Despite the efforts by all players in the construction industry, many construction projects in Nigeria and generally in the region run a high-risk poor performance by being well over budget and significantly late. The construction industry generally has poor planning and poor schedule performance. While some degree of poor planning and time schedule performance is inevitable in construction projects, it is possible to improve the project planning processes and techniques to minimize their negative impact thus improve the project performance.

There are several activities to be executed to achieve the planning stage entirely and each of these activities has different contributions to make for the project's success. These activities require significant time and effort of 
the project manager. However, it is clear that the project manager has limited time scheduled for numerous responsibilities and tasks. Hence, this study aims at determining the effects of project planning processes on the project success especially in the construction sector.

\subsection{Statement of Research Questions and Hypotheses}

This study will address the following research questions: What is the level of importance attached to project planning processes in construction projects in Nigeria? And what are the most critical planning processes, which have the highest influence on construction project success?

Hypothesis one (ho1): There is no statistically significant correlation between construction project success and the overall level of planning of a project.

Hypothesis two (ho2): There is no statistically significant correlation between construction project success and the level of usage of each planning processes.

The findings from this study will be useful in determining the level of importance attached to project planning processes in construction projects in Nigeria and to identify the most critical planning processes which have the highest influence on construction project success. Thus, this study will investigate the correlations between project planning processes and construction project success. This research aims to describe, explain, and predict the choices made at construction project planning phase of a project. The research addresses how these choices are framed and evaluated in the decision making process.

The rest of the study would be divided into the following sections: Literature review of the relevant concepts such as project planning processes, construction project success and Nigerian construction industry. Also in this section, findings from recent related studies will be reviewed. The third section discusses the methodology adopted for the purpose of the study. The fourth section presents the results and analysis while the fifth section contains the summary of findings made recommendations for the management of construction companies as well as for further studies.

\section{Literature Review}

\subsection{Conceptual and Theoretical Framework}

Planning is the second phase of a project, following initiation and prior to execution and closure (PMI, 2013). Project planning stipulates a set of decisions concerning the ways that things should be done in the future, in order to execute the plan for a desired product or service. PMI (2013) specified that the Planning Process Group consist of those processes performed to establish the total scope of the effort, define and refine the objectives, and develop the course of action required to attain those objectives. In addition, those Planning processes develop the project management plan and the project documents that will be used to carry out the project.

The goal of the planning phase of a project is to prepare the structure for project execution and control. According to Idoro (2012a), project planning and project performance are two complementary activities in project management and the basis of project success or failure is defined in project planning. The conceptual framework for this study is derived from the literature review that has identified the processes at the planning stage and suggested measures of project success of construction projects. PMBOK® (PMI, 2013) identifies the standards processes that should be performed by a project manager. Of the 47 processes identified in the guide, $24(51 \%)$ are planning processes. 19 out of 24 project planning processes identified by the PMBOK ${ }^{\circledR}$ are measured in this study. According to PMI (2013), those processes consist of "Project Management Plan, Project Scope Document, Requirements Document, Design Specification, Work Breakdown Structure, Project Schedule/ Activities list, Project Schedule/ PERT or GANTT Chart, Project Schedule/ Activity Duration Estimates, Develop Project Schedule, Project Staff Assignments, Role and Responsibility Assignments, Activity Resource Requirements, Activity Cost Estimates, Determine Budget, Quality Management Plan, Communication Management Plan, Risk Management Plan/ Risk Register, Procurement Management Plan and Stakeholder Management Plan". Therefore, in order to find out the critical planning processes from the whole on project success measured by efficiency (project schedule and cost) and effectiveness (project performance and customer satisfaction) of the project, this study followed the conceptual framework shown in Figure 1.

Project success is measured by project efficiency and project effectiveness. Youcef and Nils (2017) defines project efficiency as the production of an output in a qualified and competent way in terms of the agreed scope, cost, time and quality, where quality is not a constraint per se but is often a by-product of the other three factors (scope, time and cost). Efficiency is more about comparing the outputs of the project to its inputs. In this study, project efficiency is measured in the development of construction projects by project cost and project schedule.

According to Olsson (2008), effectiveness can be related to doing the right things and it is an external type of measurement. He added that the effectiveness of a construction process can be seen as the ability of the process to satisfy the requirements, objectives and priorities related to customers in the construction industry, primarily the project owners. Effectiveness is focused on how the construction process contributes to increased value for the owners and users. In this study, project effectiveness is measured in the development of construction projects by 
customer satisfaction and the overall project performance.

Independent

Variables

Project Planning Processes

- Project Management Plan

- Project Scope Document

- Requirements Document Design Specification

- Work Breakdown Structure (WBS)

- Project Schedule/ Activities list

- Project Schedule/ PERT or Gantt Chart

- Project Schedule/ Activity Duration Estimates

- Develop Project Schedule Network

- Project Staff Assignments

- Project Schedule/ Role and Responsibility Assignments

- Project Schedule/ Activity Resource Requirements

- Activity Cost Estimates

- Determine Budget

- Quality Management Plan

- Communications Management Plan

- Risk Management Plan/ Risk Register

- Procurement Management Plan

- Stakeholder Management Plan

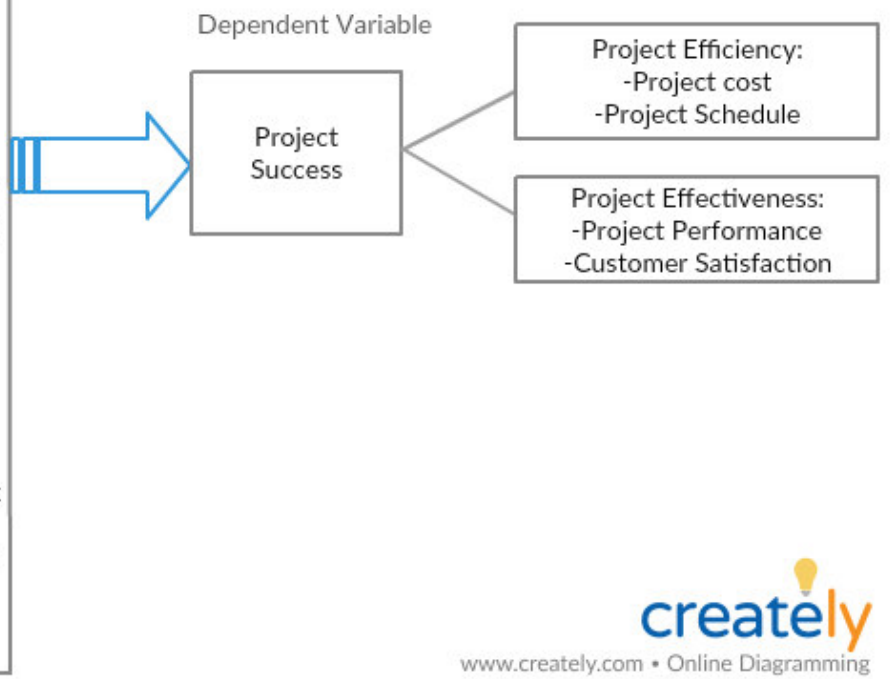

Figure 1: Conceptual Framework

However, the structure of Nigerian construction industry is very complex in that it has a wide range of different types of clients and contractors (Adamu \& Kolawole, 2011). The professionals in the industry are group of individuals often assembled into temporary and functional teams which include; architects, engineers, estate surveyors, project managers, quantity surveyors (Mudi et al., 2015). They added that this group of professionals is expected to possess the relevant skills, knowledge, tools and techniques to achieve the project goals. According to Idiake \& Bala (2012), in Nigeria the construction companies are categorized on the scope of operation, ownership and management control. Trading Economics (2019) showed that GDP from Construction in Nigeria averaged 574132.56 NGN Million from 2010 until 2019, reaching an all time high of 747860.30 NGN Million in the second quarter of 2018 and a record low of 369190.91 NGN Million in the third quarter of 2010.

However, in construction projects we make a lot of decisions in the planning phase. Most are critical and can cause the project to be successful or to fail. According to Parth (2013), decision-making is critical to being successful as a project manager and it is something we do on a daily basis as we juggle schedule, resources, risks, quality, and other factors. He also added that the academic world has taught for many years that decision-making should be rational, looking at all possible facts and logically arriving at the best solution. Therefore, decision rationality, as expressed in decision theory, economics and finance, has contaminated the conceptual underpinnings of many practical tools for project selection, organization, contact design, and activity planning (Garvin and Ford, 2012). From this perspective, project planning is a series of decision moments, in which planners choose between alternative projects or output parameters; designing a contract is allocating responsibilities and risks between parties given the uncertainties and means of control that characterize its object (von Branconi and Loch, 2004). And operational planning, guided by tools such as work breakdown structure, is a consistent programming of activities, given their anticipated length, dependencies and uncertainties.

\subsection{Empirical Review}

While planning typically is a fraction of overall project effort, it has a disproportionate impact on project success. Zwickau (2009) studied the contribution of the PMBOK® Guide's nine knowledge areas to project success. He reported that the knowledge areas related to the planning phase had the highest impact on project success "the more frequently planning processes which are related to these Knowledge Areas are performed, the better project success is". Conversely, "Cost and Procurement are the Knowledge Areas that contribute least to project success, maybe because they are practiced mainly during project execution". According to Singh et al. (2017), The 
relationship between process group planning and project success was investigated on real estate companies using Pearson product - moment correlation coefficient (r). There was a moderate, positive correlation between the two variables, $\mathrm{r}=0.475, \mathrm{n}=641, \mathrm{p}<.01$ (statistically significant). Hence, as the practice of project planning process group increases, there is a high likelihood that project success will also increase. Additionally, Zwikael (2009) conducted a study on 555 projects managers across four industries spanning three countries. He found that relative to other industrial sectors, organizations belonging to the construction sector obtained high quality of project planning and the highest success rate. He also identified that the processes that have the greatest impact on project success are "Activity Definition" and "Project Plan Development".

Similarly, Choma and Bhat (2010, p.5) analyzed 73 projects from 49 different organizations. They reported "As would be expected, the projects with the worst results were those that were missing important planning components at authorization". However, they did not find a correlation between time spent in the planning phase front end loading (FEL) and project success. Through a survey of 1,386 projects, Serrador and Turner (2015) also demonstrated that project efficiency correlates moderately strongly to overall project success. They asserted that project efficiency, which is mainly dependent on time and cost performance, is an important contributor to project success.

\section{Methodology}

In alignment with the research objectives, the research model, which is shown in Figure 1, aims at investigating the influence of 19 project planning processes on four project success measurements in the construction sector, in order to find the planning processes which have the most significant impact on project success. This research is quantitative. The research used two data collection approaches, physical (questionnaire), online surveys and literature review. A total of 70 questionnaires were administered to professionals from the selected construction companies namely Julius Berger Nigeria PLC, Bilaad Realty Nigeria and Zavati Construction. The population of the study comprised of registered project managers, consultants, engineers and contractors in three construction companies. Random sampling and purposive sampling techniques were used in this study. The research validity has been evaluated by comparing the overall planning index (PPI) with the project success. The PPI index has been calculated from the questionnaires as the average of all nineteen planning items and to test the reliability of the instrument, the Cronbach Alpha test is used. Also the statistical analyses of the two hypotheses are provided below using spearman correlation at 95\% confidence level. Statistical Package for Social Sciences (SPSS) is used for the statistical analysis for the questionnaire.

\section{Results}

\subsection{Descriptive Statistics}

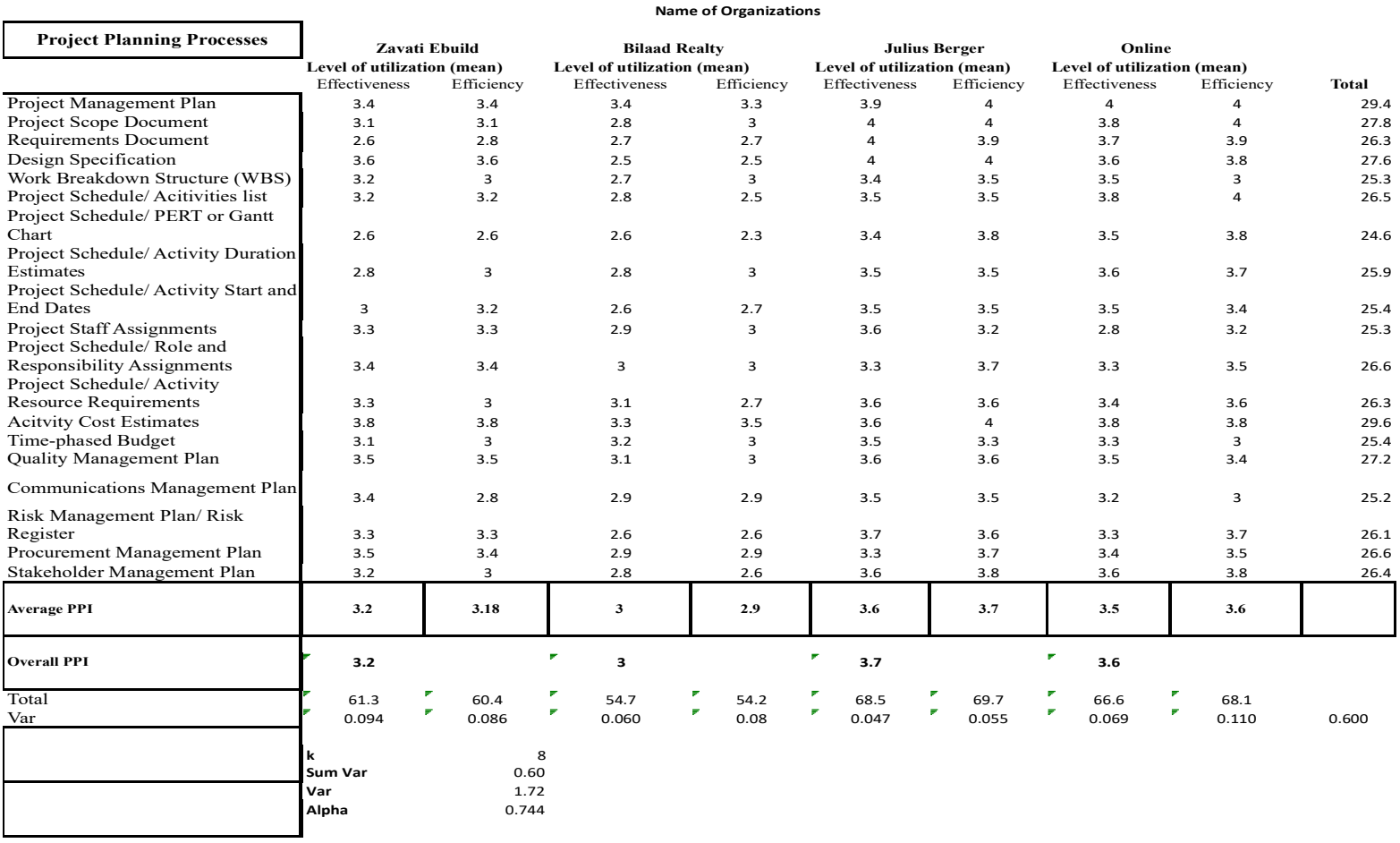

Table 1: Validity and Cronbach Alpha Test of Reliability for the Instrument 


\section{Statistics}

\begin{tabular}{llr} 
position & & \\
$\mathrm{N}$ & Valid & 60 \\
\cline { 2 - 3 } & Missing & 6 \\
\hline
\end{tabular}

\begin{tabular}{|c|c|c|c|c|c|}
\hline & & \multicolumn{2}{|c|}{ position } & & \multirow[b]{2}{*}{$\begin{array}{l}\text { Cumulative } \\
\text { Percent }\end{array}$} \\
\hline & & Frequency & Percent & Valid Percent & \\
\hline \multirow[t]{6}{*}{ Valid } & Owner/Client & ( & 6.1 & 6.7 & 6.7 \\
\hline & Contractor & 6 & 9.1 & 10.0 & 16.7 \\
\hline & Consultant & 13 & 19.7 & 21.7 & 38.3 \\
\hline & Project manager & 27 & 40.9 & 45.0 & 83.3 \\
\hline & Engineer & 10 & 15.2 & 16.7 & 100.0 \\
\hline & Total & 60 & 90.9 & 100.0 & \\
\hline Missing & System & 6 & 9.1 & & \\
\hline Total & & 66 & 100.0 & & \\
\hline
\end{tabular}

Table 2: Position held by Respondents

\subsection{Correlation Results}

Hypothesis one: There is no statistically significant correlation between construction project success and the overall level of planning of a project.

\section{Correlations}

PROJET

EFFECTIVENESS EFFICIENCY SUCCESS

\begin{tabular}{llll|l|l}
\hline Spearman's rho & TOTAL LEVEL OF & Correlation & -.259 & -.618 & -.493 \\
& PLANNING & Coefficient & & & \\
\cline { 2 - 5 } & & Sig. (2-tailed) & .283 & .005 & .032 \\
\cline { 2 - 6 } & & $\mathrm{N}$ & 60 & 60 & 60 \\
\hline
\end{tabular}

\section{Table 3: Correlation between Level of Planning and Project Success}

Hypothesis Two: There is no statistically significant correlation between construction project success and the level of usage of each planning processes.

Correlations

PROJET

EFFECTIVENESS EFFICIENCY SUCCESS

\begin{tabular}{|c|c|c|c|c|c|}
\hline \multirow[t]{21}{*}{ Spearman's rho } & \multirow{3}{*}{$\begin{array}{l}\text { Project } \\
\text { Management Plan }\end{array}$} & Correlation Coefficient & .306 & .014 & .194 \\
\hline & & Sig. (2-tailed) & .017 & .914 & .137 \\
\hline & & $\mathrm{N}$ & 60 & 60 & 60 \\
\hline & \multirow{3}{*}{$\begin{array}{l}\text { Project } \\
\text { Document }\end{array}$} & eCorrelation Coefficient & .234 & .108 & .172 \\
\hline & & Sig. (2-tailed) & .072 & .410 & .190 \\
\hline & & $\mathrm{N}$ & 60 & 60 & 60 \\
\hline & \multirow{3}{*}{$\begin{array}{l}\text { Requirements } \\
\text { Document }\end{array}$} & Correlation Coefficient & .427 & .015 & .242 \\
\hline & & Sig. (2-tailed) & .001 & .912 & .062 \\
\hline & & $\mathrm{N}$ & 60 & 60 & 60 \\
\hline & \multirow{3}{*}{$\begin{array}{l}\text { Design } \\
\text { Specification }\end{array}$} & Correlation Coefficient & .433 & .028 & .287 \\
\hline & & Sig. (2-tailed) & .001 & .833 & .026 \\
\hline & & $\mathrm{N}$ & 60 & 60 & 60 \\
\hline & \multirow{3}{*}{$\begin{array}{l}\text { Work Breakdow } \\
\text { Structure }\end{array}$} & Correlation Coefficient & .523 & .319 & .513 \\
\hline & & Sig. (2-tailed) & .000 & .013 & .000 \\
\hline & & $\mathrm{N}$ & 60 & 60 & 60 \\
\hline & \multirow[t]{3}{*}{ Activities List } & Correlation Coefficient & .286 & .044 & .205 \\
\hline & & Sig. (2-tailed) & .027 & .738 & .116 \\
\hline & & $\mathrm{N}$ & 60 & 60 & 60 \\
\hline & \multirow{3}{*}{$\begin{array}{l}\text { PERT } \\
\text { Chart }\end{array}$} & tCorrelation Coefficient & .474 & .314 & .496 \\
\hline & & Sig. (2-tailed) & .000 & .014 & .000 \\
\hline & & $\mathrm{N}$ & 60 & 60 & 60 \\
\hline
\end{tabular}




\begin{tabular}{|c|c|c|c|c|}
\hline \multirow{3}{*}{$\begin{array}{l}\text { Activity Duratio } \\
\text { Estimate }\end{array}$} & onCorrelation Coefficient & .293 & .062 & .198 \\
\hline & Sig. (2-tailed) & .023 & .638 & .129 \\
\hline & $\mathrm{N}$ & 60 & 60 & 60 \\
\hline \multirow{3}{*}{$\begin{array}{l}\text { Project Schedul } \\
\text { Network }\end{array}$} & leCorrelation Coefficient & .323 & .322 & .408 \\
\hline & Sig. (2-tailed) & .012 & .012 & .001 \\
\hline & $\mathrm{N}$ & 60 & 60 & 60 \\
\hline \multirow{3}{*}{$\begin{array}{l}\text { Project Staf } \\
\text { Assignments }\end{array}$} & iffCorrelation Coefficient & .289 & -.161 & .077 \\
\hline & Sig. (2-tailed) & .025 & .219 & .560 \\
\hline & $\mathrm{N}$ & 60 & 60 & 60 \\
\hline \multirow{3}{*}{$\begin{array}{l}\text { Role } \\
\text { Responsibility } \\
\text { Assignments }\end{array}$} & adCorrelation Coefficient & .032 & -.185 & -.096 \\
\hline & Sig. (2-tailed) & .806 & .156 & .466 \\
\hline & $\mathrm{N}$ & 60 & 60 & 60 \\
\hline \multicolumn{2}{|c|}{ Activity ResourceCorrelation Coefficient } & -.107 & .085 & .004 \\
\hline \multirow[t]{2}{*}{ Requirements } & Sig. (2-tailed) & .414 & .520 & .978 \\
\hline & $\mathrm{N}$ & 60 & 60 & 60 \\
\hline \multirow{3}{*}{$\begin{array}{l}\text { Activity } \\
\text { Estimates }\end{array}$} & stCorrelation Coefficient & .204 & .031 & .094 \\
\hline & Sig. (2-tailed) & .119 & .814 & .474 \\
\hline & $\mathrm{N}$ & 60 & 60 & 60 \\
\hline \multirow[t]{3}{*}{ Determine Budget } & t Correlation Coefficient & .290 & .277 & .335 \\
\hline & Sig. (2-tailed) & .025 & .032 & .009 \\
\hline & $\mathrm{N}$ & 60 & 60 & 60 \\
\hline \multirow{3}{*}{$\begin{array}{l}\text { Quality } \\
\text { Management Plan }\end{array}$} & Correlation Coefficient & .248 & .304 & .376 \\
\hline & Sig. (2-tailed) & .056 & .018 & .003 \\
\hline & $\mathrm{N}$ & 60 & 60 & 60 \\
\hline \multirow{3}{*}{$\begin{array}{l}\text { Communication } \\
\text { Management Plan }\end{array}$} & Correlation Coefficient & .436 & -.174 & .142 \\
\hline & Sig. (2-tailed) & .000 & .184 & .279 \\
\hline & $\mathrm{N}$ & 60 & 60 & 60 \\
\hline \multirow{3}{*}{$\begin{array}{l}\text { Risk } \\
\text { Plan }\end{array}$} & ntCorrelation Coefficient & .078 & .068 & .072 \\
\hline & Sig. (2-tailed) & .552 & .606 & .582 \\
\hline & $\mathrm{N}$ & 60 & 60 & 60 \\
\hline \multirow{3}{*}{$\begin{array}{l}\text { Procurement } \\
\text { Management Plan }\end{array}$} & Correlation Coefficient & .231 & .098 & .161 \\
\hline & Sig. (2-tailed) & .075 & .455 & .220 \\
\hline & $\mathrm{N}$ & 60 & 60 & 60 \\
\hline \multirow{3}{*}{$\begin{array}{l}\text { Stakeholder } \\
\text { Management Plan }\end{array}$} & Correlation Coefficient & .272 & -.040 & .156 \\
\hline & Sig. (2-tailed) & .035 & .761 & .234 \\
\hline & $\mathrm{N}$ & 60 & 60 & 60 \\
\hline
\end{tabular}

Table 4: Correlation between construction project success and the level of usage of each project planning process

\subsection{Discussion of Findings}

Analysis of hypothesis one explored the relationship between the level of planning observed on construction projects and the success of these projects. We found a statistically significant correlation between the overall level of planning applied to construction projects and both the efficiency component of project success and total project success. The correlation between level of planning and project effectiveness was not statistically significant. Thus, this implies that construction projects were completed as scheduled and according to budget or plan. However, even though those construction projects were considered a success and the projects objectives were completed, the quality of the result was not always perceived as expected.

The overall level of planning as measured in this study is a function of the level of usage of nineteen individual project planning processes. Analysis of hypothesis two found that use of five individual planning processes out of nineteen had a statistically significant correlation with total project success measured by project efficiency and project effectiveness. This means that project managers, in the construction sector do not consider some planning processes while planning their projects. In addition, this study also found that use of several individual planning processes had a significant correlation with project effectiveness only. Use of project management plan, requirements document, activities list, Activity duration estimate, project staff assignments, communication management plan and stakeholder management plan were most effective in supporting project success. Use of requirements document was the planning process that had a significant correlation with project effectiveness 
among the rest. It can be speculated that clear definition of product requirements early in the project will allow clear assignment and execution of tasks to complete the project on schedule. Creation of the Work Breakdown Structure has been found the most critical planning process for the construction sector, significantly influencing project success. However, some planning processes receive less attention than is expected. Use of Project Scope Document, Activity Resource Requirements, Role and Responsibility Assignments, Risk Management Plan, Project Staff Assignments and Procurement Management Plan processes displayed a relatively low usage.

\section{Conclusion}

\subsection{Summary of Findings}

The results of study reported in this research work indicate a significant effect of the use of processes related to project planning on project success, especially in carrying out construction projects. Additionally, the results obtained from the assessment of both variables demonstrate a significant level of project management processes. However, not all of the 19 project planning processes analyzed in this study and included in the PMBOK have an equal impact on project success. The six processes with the highest impact include Work breakdown Structure, utilization of PERT or Gantt Chart in the project, Development of a Project Schedule Network, Quality Management Plan, Determination of the Project Budget and Design Specification of the Project.

By far, the Creation of the Work Breakdown Structure (WBS) is the most significantly critical planning process. This process is part of the project scope document knowledge area and is detailed described in the project management literature. In order to correctly execute this planning process, a project manager has to define activities. Then, decomposition is required, subdividing the project work packages into smaller, more manageable components, called activities. The two low impact processes include: Risk Management Plan and Activity Resource Requirements. Obviously, it is impossible to execute a project without performing these processes. One may also assumes that each project manager may perform the above processes in different ways, without his awareness concerning their actual execution.

\subsection{Recommendations}

Based upon the above conclusion and findings of the study, this research work is focused on the following recommendations to enhance the use of project planning processes by project managers in the creation of construction projects in Nigeria.

i. This research work recommends the use of a formal and structured project planning processes and with the involvement of project mangers in the construction sector in Nigeria.

ii. Professionals in the industry such as project managers, engineers, contractors should explore more frequent use of some other project planning processes like risk management plan, activity resource requirements in other to see better realization of construction projects.

iii. This study also proposes continuous development seminars and trainings in project management for all organizations in Nigeria and especially those in construction projects planning and procurement departments of both private and government organizations.

iv. Project managers should always and in a continuous manner, plan, do, check and act, throughout the creation process of construction projects, in other to see continuous improvements.

\section{Reference}

Adamu, M., \& Kolawole, B. O. (2011). The role of construction industry in arresting rural urban drift in Nigeria. Journal of Environmental Research and Policies, 6(3), 83-94.

Ameh O. J. and Odusami K. T. (2010) . Professionals' Ambivalence toward Ethics in the Nigerian Construction Industry. Journal of Professional Issues in Engineering Education and Practice. 136 (1),9. doi.org/10.1061/(ASCE)1052-3928(2010)136:1(9)

Choma, A. A. \& Bhat, S. (2010). Success vs. failure: what is the difference between the best and worst projects? In Proceedings PMI Global Congress 2010 - Washington D. C.

Garvin, M. J., \& Ford, D. N. (2012). Real options in infrastructure projects: theory, practice and prospects. Engineering Project Organization Journal, 2(1-2), 97-108 .doi:10.1080/21573727.2011.632096

Idiake, J.E. \& Bala, K. (2012). Improving Labour Productivity in Masonry Works in Nigeria: The Application of Learn Management Technique. Proceedings of $4^{\text {th }}$ West-Africa Built Environment Research (WABER) Conference, Abuja, Nigeria.

Idoro, G. I. (2012a). The Influence of Project Documents on the Outcome of Construction Projects Procured by Traditional Methods in Nigeria. Journal of Construction in Developing Countries, 17 (1), 1-19. Retrieved from http://web.usm.my/jcdc/vol17 1 2012/Art\%201 jcdc17-1.pdf

Menches, C., Hanna, A., Nordheim, E. and Russell, J. (2008), Impact of pre-construction planning and project characteristics on performance in the US electrical construction industry. Construction Management and Economics. (26)8, 855-869. doi.org/10.1080/01446190802213511 
Mudi, A., Bioku, J., \& Kolawole, O. (2015). Assessing the characteristics of Nigerian construction industry in infrastructure development. International Journal of Engineering Research \& Technology. 4(11), 546-555. Retrieved

from https://www.researchgate.net/profile/Mudi_Adamu/publication/284719773_Assessing the_Characteristics of Nigerian Construction Industry in Infrastructure Development/links/5657100b08ae1 ef9297b924d.pdf

Nigeria - Construction Equipment (2018). Retrieved from https://www.export.gov/article?id=NigeriaConstruction-Equipment

Nigeria GDP from Construction (n.d). Available at https://tradingeconomics.com/nigeria/gdp-from-construction

Olawale, A., \& Sun, M. (2010). Cost and Time Control of Construction Projects: Inhibiting Factors and Mitigating Measures in Practice. Construction Management and Economics. 28(5), 509- 526. doi.org/10.1080/01446191003674519

Olsson, N.O.E. (2008), Conflicts related to effectiveness and efficiency in Norwegian rail and hospital projects. Project Perspectives. 29(1), 81-85. Retrieved from https://www.researchgate.net/profile/Nils_Olsson2/publication/228875096_Conflicts_related_to_effectiven ess_and_efficiency_in_Norwegian_rail_and_hospital_projects/links/0c96052975209943b1000000.pd

Parth, F. R. (2013). Critical decision-making skills for project managers. Paper presented at PMI® Global Congress -EMEA, Istanbul, Turkey. Newtown Square, PA: Project Management Institute.

PMI. (2013). A guide to the project management body of knowledge: PMBOK® guide (5th ed.). Newtown Square, PA: Project Management Institute

Serrador, P., \& Turner, R. (2015). The relationship between project success and project efficiency. Project Management Journal. 46(1), 30- 39. doi.org/10.1002\%2Fpmj.21468

Singh, A. P, Singh, R. (2017). Impact of Project Management Process Groups on Project Success: A Case of Real Estate Companies. International Journal of Latest Engineering and management Research, 09(2), 01-12. Available at http://www.ijlemr.com/papers/volume2-issue9/1-IJLEMR-22432.pdf

Von Branconi, C., \& Loch, C. H. (2004). Contracting for major projects: eight business levers for top management. International Journal of Project Management, 22(2), 119-130.doi:10.1016/s0263-7863(03)00014-0

Youcef J-T. Zidane, Nils O.E. Olsson, (2017), Defining project efficiency, effectiveness and efficacy, International Journal of Managing Projects in Business, 10(3), 621- 641.doi.org/10.1108/IJMPB-10-20160085

Zwickau, O. (2009). The relative importance of the PMBOK ${ }^{\circledR}$ Guide's nine Knowledge Areas during project planning. Project Management Journal.40 (4), 94-103. doi.org/10.1002\%2Fpmj.20116

Zwikael, Ofer, 2009. Critical planning processes in construction projects. Construction Innovation. 9 (4), 372 387.doi.org/10.1108/14714170910995921 